\title{
Kebebasan Memilih Pihak dalam Kontrak pada Asas Kebebasan Berkontrak dalam Sewa Menyewa Kamar Tinggal
}

\author{
Annisa Syaufika Y. R. dan Sa'ida Rusdiana \\ Fakultas Hukum Universitas Gajah Mada Yogyakarta \\ Jln. Sosio Yustisia No. 1, Bulaksumur, Kab. Sleman, D.I. Yogyakarta \\ annisa.syaufika@ugm.ac.id; sahyde_666@yahoo.com
}

Received: 26 September 2017; Accepted: 8 Mei 2018; Published: 14 Agustus 2018

DOI: 10.20885/iustum.vol25.iss1.art6

\begin{abstract}
One of the scopes of freedom of contract is to freely determine with whom a person makes an agreement. In terms of renting a boarding house in Indonesia, it is often found that the owners of boarding houses only allow Muslim tenants by installing a sign saying "Terima Kost Muslim". The objective of this study was to examine the issues of: first, the meaning of freedom to choose partner in the principle of freedom of contract in the Installation of a Board saying "Terima Kost Muslim", and second, the restriction on freedom to choose partner in boarding house tenancy agreement related to the installation of a Board "Terima Kost Muslim". This was a normative legal research with literature study that aimed to obtain secondary data by reviewing legislation, literature, and other relevant legal materials. The data obtained were then analyzed qualitatively. The conclusions are, first, the meaning and freedom in choosing partner in a boarding house tenancy agreement are that everyone is free to bind him/herself in an agreement by mentioning an offer to a particular party. Second, things that restrict the freedom to choose partner in a boarding house tenancy agreement are the principles of antidiscrimination, legislation and propriety in society.
\end{abstract}

Keywords: Freedom of contract; tenancy agreement

Abstrak

Salah satu cakupan kebebasan berkontrak adalah bebas memilih dengan siapa seseorang membuat perjanjian. Dalam praktek sewa kost di Indonesia, sering ditemukan pemilik tempat tinggal yang hanya menerima penyewa Muslim dengan memasang papan bertuliskan "Terima Kost Muslim". Penelitian ini bertujuan untuk mengkaji permasalahan: pertama, pemaknaan kebebasan memilih pihak dalam asas kebebasan berkontrak pada Pemasangan Papan "Terima Kost Muslim", dan kedua, pembatasan dalam kebebasan memilih pihak pada perjanjian sewa kost terkait Pemasangan Papan "Terima Kost Muslim" tersebut. Penelitian ini merupakan penelitian normatif yuridis dengan studi pustaka yang bertujuan untuk memperoleh data sekunder dengan mengkaji peraturan perundang-undangan, literatur, dan bahanbahan hukum lain yang relevan. Data yang diperoleh kemudian dianalisis secara kualitatif. Kesimpulannya pertama, pemaknaan dan kebebasan dalam memilih pihak dalam perjanjian sewa kost adalah setiap orang bebas mengikatkan diri dalam sebuah perjanjian dengan mencantumkan penawaran kepada pihak tertentu. Kedua, hal-hal yang membatasi kebebasan memilih pihak dalam perjanjian sewa kost adalah asas anti-diskriminasi, peraturan perundang-undangan, dan kepatutan dalam masyarakat..

Kata-kata Kunci: kebebasan berkontrak; perjanjian sewa 


\section{Pendahuluan}

Asas kebebasan berkontrak memungkinkan para pihak untuk membuat perjanjian sesuai dengan kehendaknya. Asas ini didukung dengan dinamika ekonomi pasar bebas dan individualisme dalam masyarakat. Tujuan dari pemikiran kebebasan berkontrak adalah mendatangkan kesejahteraan seoptimal mungkin.

Asas kebebasan berkontrak dapat ditemukan dalam Pasal 1338 ayat (1) KUHPerdata yang menyebutkan: "Semua perjanjian yang dibuat secara sah berlaku sebagai undang-undang bagi mereka yang membuatnya." Pasal tersebut berkaitan dengan penjabaran dari asas kebebasan berkontrak, dari kata "semua" tersimpul kebebasan untuk: 1. bebas untuk membuat perjanjian atau tidak membuat perjanjian; 2 . bebas untuk membuat perjanjian dengan siapapun; 3 . bebas mengatur bentuk perjanjian yang dibuatnya; 4 . bebas mengatur isi dan syarat perjanjian yang dibuatnya; 5 . bebas mengadakan pilihan hukum.

Salah satu cakupan kebebasan berkontrak adalah kebebasan untuk memilih pihak dengan siapa seseorang ingin membuat perjanjian. ${ }^{1}$ Cakupan tersebut bermakna seseorang dapat memilih atau menolak untuk membuat perjanjian dengan orang lain berdasarkan pertimbangan subjektif atau objektif dirinya. Pertimbangan yang digunakan sangat erat kaitannya dengan tujuan perjanjian yang akan dibuat, misal dalam perjanjian kerja pertimbangan dalam memilih pekerja adalah kualifikasi dan kemampuan seseorang untuk mengisi posisi tertentu.

Penolakan terhadap seseorang untuk menjadi pihak dalam perjanjian menyebabkan hilangnya kesempatan-kesempatan yang akan didapatkan seperti pelayanan, pekerjaan, dan kebutuhan dasar. Penolakan menjadi adil ketika pertimbangan yang digunakan bersifat rasional dan sesuai dengan tujuan perjanjian. Penolakan menjadi tidak adil ketika pertimbangan yang digunakan berdasarkan ras, etnis, dan agama.

Permasalahan diskriminasi yang serius dalam pembentukan kontrak terjadi di Amerika Serikat dimana ras Afro-Amerika dan Hispanic sering menerima

${ }^{1}$ Sutan Remy Sjahdeini, Kebebasan Berkontrak dan Perlindungan yang Seimbang Bagi Para Pihak Dalam Perjanjian Kredit Bank di Indonesia, Cetakan Pertama, Pustaka Utama Grafiti, Jakarta, 2009, hlm. 54. 
perlakuan diskriminatif dan penolakan dalam proses pembentukan perjanjian kerja, perjanjian kredit, serta sewa dan jual beli tempat tinggal. ${ }^{2}$ Walaupun terjadi penurunan dibandingkan beberapa dekade yang lalu, dalam praktek diskriminasi dalam pembentukan kontrak tersebut masih bisa dirasakan hingga saat ini. Beberapa studi empiris yang dilakukan di berbagai negara menunjukkan bukti nyata adanya praktek diskriminasi khususnya dalam sewa dan jual beli tempat tinggal. ${ }^{3}$

Pertimbangan dalam pemilihan pihak perjanjian berdasarkan agama terjadi pada perjanjian sewa tempat tinggal atau kost di beberapa wilayah di Indonesia. ${ }^{4}$ Beberapa pemilik rumah yang beragama Islam hanya menerima penyewa yang beragama Islam. Ada pemilik rumah yang menyatakan pilihan tersebut secara terang-terangan dengan memasang papan bertuliskan "Terima Kost Muslim". Pada perjanjian sewa tempat tinggal, tujuan penyewa adalah untuk mendapatkan tempat tinggal dan fasilitasnya, sementara tujuan pemilik tempat tinggal adalah mendapatkan keuntungan dari pembayaran biaya sewa. Dalam memilih pihak dalam perjanjian sewa ini adalah kemauan pihak dalam mentaati peraturan sewa dan kemampuan untuk membayar sewa, sehingga pertimbangan agama dan ras menjadi tidak relevan.

Pada dasarnya setiap orang dilahirkan bebas dengan harkat dan martabat yang sama dan sederajat. Undang-Undang Dasar 1945 menjamin bahwa setiap orang bebas dari perlakuan yang bersifat diskriminatif ${ }^{5}$ atas dasar apapun dan

\footnotetext{
${ }^{2}$ Devah Pager \& Hana Shepherd, "The Sociology of Discrimination in Employment, Housing, Credit, and Consumer Marke”t, Annu Rev Spciol. 2008 January 1.

3 Diskriminasi yang signifikan terhadap ras Afro-Amerika di beberapa kota di Amerika Serikat dalam Andrew Hanson \& Zackary Hawley, "Do Lanlords Discriminate in The Rental Housing Market? Evidence from an Internet Field Experiment in US Cities”, Journal of Urban Economics 70, 2011.

Dalam pasar penyewaan tempat tinggal di Italia, diskriminasi paling banyak dialami oleh orang yang berasal dari Arab dan Eropa Timur. Massimo Baldini et. al., Ethnic Discrimination in The Italian Rental Housing Market, Journal of Housing Economics Vol. 20, 2011.

Diskriminasi dalam penyewaan tempat tinggal juga terjadi di Swedia. Magnus Carlsson \& Stefan Eriksson, Discrimination in The Rental Market for Apartments, Journal of Housing Economics Vol. 23, 2014.

4 Edi Purwanto, Eksklusivisme Itu Berlabel Kos Muslim, https://jendelapemikiran.wordpress.com/ 2008/05/26/ekslusivitas-berlabel-kos-muslim/, diakses pada 4 Juli 2015 19:15.

${ }^{5}$ Diskriminasi menurut Pasal 1 Undang-Undang Nomor 39 Tahun 1999 tentang Hak Asasi Manusia adalah setiap pembatasan setiap pembatasan, pelecehan, atau pengucilan yang langsung ataupun tak langsung didasarkan pada pembedaan manusia atas dasar agama, suku, ras, etnik, kelompok, golongan, status sosial, status ekonomi, jenis kelamin, bahasa, keyakinan politik, yang berakibat pengurangan, penyimpangan atau penghapusan pengakuan, pelaksanaan atau penggunaan hak asasi manusia dan kebebasan dasar dalam kehidupan baik individual maupun kolektif dalam bidang politik, ekonomi, hukum, sosial, budaya, dan aspek kehidupan lainnya.
} 
berhak mendapatkan perlindungan terhadap perlakuan yang bersifat diskriminatif itu. Pemilihan pihak dalam perjanjian berdasarkan agama merupakan salah satu bentuk pembatasan yang dapat bertentangan dengan asas anti diskriminasi yang dianut oleh Undang-Undang Nomor 39 tentang Hak Asasi Manusia karena terdapat perlakuan yang berbeda terhadap pihak yang agamanya berbeda.

Secara umum kebebasan berkontrak dapat menimbulkan ketidakadilan dikarenakan posisi tawar para pihak yang tidak seimbang. Dalam perkembangannya kebebasan berkontrak dibatasi melalui peraturan perundangundangan, ketertiban umum, dan kesusilaan. ${ }^{6}$ Untuk membatasi kebebasan para pemilik tempat tinggal dalam melakukan diskriminasi dalam pemilihan pihak, Kongres di Amerika Serikat membuat undang-undang yang melarang diskriminasi dalam sewa tempat tinggal dengan dasar ras, warna, agama, jenis kelamin, dan bangsa dalam Fair Housing Act. ${ }^{7}$

Di Indonesia pelarangan diskriminasi berkaitan dengan hak-hak ekonomi bagi setiap individu belum secara khusus diatur. Dalam menyelesaikan tarik menarik antara asas kebebasan berkontrak dan anti diskriminasi ini perlu dilakukan kajian secara khusus mengenai pemaknaan dan kemungkinan pembatasan "bebas memilih dengan siapa seseorang ingin membuat perjanjian" pada asas kebebasan berkontrak. Walaupun pada praktik usaha penyewaan kamar tinggal terdapat beberapa macam pembatasan dari karakteristik agama, gender, dan ras, tulisan ini hanya mengkaji tentang pembatasan berdasarkan agama, khususnya pada pemasangan papan “Terima Kost Muslim” oleh pemilik tempat tinggal.

\section{Rumusan Masalah}

Permasalahan yang diangkat dalam penelitian ini adalah mengenai pertama, bagaimanakah pemaknaan "bebas memilih dengan siapa seseorang ingin membuat perjanjian" dalam asas kebebasan berkontrak pada Pemasangan Papan “Terima Kost Muslim"? Kedua, apakah ada pembatasan dalam "bebas memilih

\footnotetext{
${ }^{6}$ Ridwan Khairandy, Hukum Kontrak di Indonesia Dalam Perspektif Perbandingan (Bagian Pertama), Cetakan Kedua, FH UII Press, Yogyakarta, 2014, hlm. 88-89.

${ }^{7}$ Edward H. Rabin, "Revolution in Residential Lanlord-Tenant Law: Causes and Consequences", Cornell Law Review Vol. 69, 1984, hlm. 531.
} 
dengan siapa seseorang ingin membuat perjanjian" pada Pemasangan Papan “Terima Kost Muslim" tersebut?

\section{Tujuan Penelitian}

Sebagai tindak lanjut dari rumusan masalah yang telah ditetapkan di atas, maka tujuan dilakukannya penelitian ini adalah: Pertama, mengetahui pemaknaan "bebas memilih dengan siapa seseorang ingin membuat perjanjian" dalam asas kebebasan berkontrak pada Pemasangan Papan "Terima Kost Muslim". Kedua, mengetahui pembatasan dalam "bebas memilih dengan siapa seseorang ingin membuat perjanjian" pada Pemasangan Papan "Terima Kost Muslim" tersebut?

\section{Metode Penelitian}

Penelitian ini bersifat yuridis normatif dan merupakan penelitian kepustakaan yang bertujuan mendapatkan data sekunder dengan cara melakukan penelaahan terhadap peraturan perundang-undangan, literatur, karya-karya hukum, dan bahan-bahan tertulis lainnya yang berkaitan dengan penelitian. Data yang diperoleh dari penelitian kepustakaan selanjutnya dianalisis secara kualitatif. Data yang terkumpul kemudian dikelompokkan dan dipilah-pilah dicari yang relevan dan representatif yang berhubungan dengan pokok permasalahan.

\section{Hasil Penelitian dan Pembahasan}

\section{Pemaknaan "Bebas Memilih dengan Siapa Seseorang ingin Membuat Perjanjian" dalam Asas Kebebasan Berkontrak pada Pemasangan Papan "Terima Kost Muslim"}

Setiap kontrak umumnya dibentuk dengan diawali oleh adanya penawaran atau tawar menawar di antara calon pihak dalam kontrak. Kegiatan tersebut terletak pada fase pra kontrak. Penawaran dari calon pihak yang satu atau dikenal dengan offer atau offert, yang isinya menggambarkan pernyataan kehendak yang ditujukan kepada calon lawannya, diharapkan akan memperoleh jawaban yang berisi penerimaan dari calon lawan atau dikenal dalam bahasa asing dengan 
sebutan acceptance atau acceptation atau acceptasi. Jika hal itu sungguh terjadi maka kita melihat adanya persetujuan/consensus atau tercapai kata sepakat. ${ }^{8}$

Dalam fase prakontraktual terdapat kegiatan yang dilakukan calon subjek kontrak, yaitu yang dikenal dengan sebutan negosiasi (pourparler/negotiation) atau perundingan. KUHP maupun Kitab Undang-Undang Hukum Perdata sistem hukum Eropa Kontinental yang lain tidak mengatur secara khusus mengenai negosiasi. Demikian pula dalam sistem hukum Amerika, pengaturan secara khusus mengenai negosiasi juga tidak ada. Akan tetapi bila kita mencermati proses pembentukan kontrak dalam sistem hukum yang ada di dunia, negosiasi merupakan bagian dalam proses tersebut dan terletak dalam fase prakontraktual, yaitu tahapan sebelum kontrak itu terjadi atau lahir atau terbentuk. ${ }^{9}$ Hal yang terpenting dalam negosiasi bukannya untuk menang atau kalah, melainkan diusahakan agar kedua belah pihak sama-sama memperoleh kepuasan karena keinginan dan kebutuhannya sama-sama dipenuhi. ${ }^{10}$

Negosiasi merupakan sarana bagi para pihak untuk mengadakan komunikasi dua arah yang dirancang untuk mencapai kesepakatan sebagai akibat adanya perbedaan pandangan terhadap sesuatu hal dan dilatarbelakangi oleh kesamaan/ketidaksamaan kepentingan diantara mereka. ${ }^{11}$ Berkaitan dengan proses negosiasi yang dilalui oleh seseorang yang hendak mengikatkan diri dalam suatu perjanjian pada prinsipnya bertujuan untuk mencapai kata sepakat. Guna memperoleh sepakat tersebut pastilah seseorang ia akan berkontrak dengan pihak yang memenuhi syarat, standar dan kriteria sebagai lawan berkontrak, baik untuk melindungi kepentingannya maupun mencapai kepuasan keingan tertentu dalam berkontrak.

Seseorang karena kedudukannya atau kekuasaan tertentu yang dimilikinya terkadang melekatkan syarat, kriteria atau standar tertentu kepada pihak lain untuk dapat mengikatkan diri. Seperti halnya dalam kasus pencantuman papan bertuliskan "Terima Kost Muslim" oleh pemilik tempat/rumah kost merupakan

${ }^{8}$ F.X. Suhardana, Contract Drafting (Kerangka Dasar dan Teknik Penyusunan Kontrak), Universitas Atma Jaya, Yogyakarta, 2008, hlm. 84.

${ }^{9}$ F.X. Suhardana, Op. Cit., hlm. 88-89.

${ }^{10}$ Ibid., hlm. 89.

11 Salim H.S., Op.Cit., hlm. 123. 
salah satu wujud tindakan atau perilaku sepihak yang mencerminkan adanya kekuasaan yang dimiliki oleh seseorang untuk menunjukkan adanya kehendak atau keinginannya kepada pihak lainnya.

Pemilik rumah kost selaku pihak yang menyewakan dapat dikatakan memiliki kedudukan yang lebih kuat dibandingkan dengan pihak penyewa. Pihak yang menyewakan memiliki kekuasaan untuk menentukan syarat-syarat yang harus dipenuhi pihak lawan berkontrak yang dituangkan dalam penawaran. Pihak yang memiliki kebutuhan untuk mengikatkan diri dalam perjanjian sewa lebih ada pada pihak penyewa. Dengan demikian, pihak penyewa harus menyesuaikan diri atau memenuhi syarat-syarat yang ditentukan oleh pihak yang menyewakan.

Dalam pembentukan perjanjian, pembentukan kehendak orang yang berbuat sebagaimana terejawantahkan melalui pembentukan pengharapan mempunyai peran penting. Bahkan dapat disimpulkan bahwa walaupun kehendak merupakan "kehendak subjektif", namun kehendak ini tidak niscaya merupakan kehendak dengan maksud-maksud egois. ${ }^{12}$

Setiap orang bebas memilih dengan siapa ingin membuat perjanjian sewa menyewa tanpa ada paksaan dari pihak manapun juga. Pihak yang menyewakan memiliki kebebasan untuk memilih calon penyewa sesuai dengan persyaratan tertentu, standar atau kriteria yang diinginkan sesuai dengan keyakinan yang dianutnya. Standar merupakan suatu ukuran tertentu yang dipakai sebagai patokan untuk memilih yang sebaik-baiknya atau kesepakatan yang telah didokumentasikan dalam bentuk tertentu. Pihak yang menyewakan memiliki hak yang bebas untuk mengikatkan diri atau tidak dengan seseorang dapat dikatakan merupakan kehendak subjektif. Subjektifitas selalu melekat pada diri setiap orang yang akan membawa pengaruh terhadap pola pikir, pandangan dan tindakan dalam kehidupannya sehari-hari, termasuk dalam hal berkontrak.

Tindakan menyewakan kamar ini merupakan bentuk tindakan hukum dalam menikmati sebuah hak kebendaan. Pemilik bangunan sebagai pemegang hak milik atas benda memiliki kebebasan dalam menikmati hak kebendaannya. Beberapa bentuk kebebasan dalam konteks ini adalah untuk menyewakannya dan memilih

${ }^{12}$ Herlien Budiono, Op. Cit., hlm. 317. 
siapa yang dapat menjadi penyewa. Pertimbangan terhadap perlindungan kepentingan hak kebendaan menjadi hal yang penting dalam pemilihan penyewa.

Pertimbangan bagi penerimaan atau penolakan terhadap seseorang untuk menjadi pihak dalam perjanjian erat kaitannya dengan pencapaian tujuan perjanjian dan perlindungan fungsi bisnis. Pertimbangan dalam perjanjian sewamenyewa tempat tinggal tidak hanya tentang kemampuan ekonomi penyewa untuk membayar sewa, tetapi juga mencakup karakter penyewa. ${ }^{13}$ Karakter penyewa merupakan faktor penentu kepatuhan penyewa terhadap aturan main dalam suatu tempat tinggal.

Pemasangan papan “Terima Kost Muslim" sesungguhnya adalah suatu bentuk penawaran yang di dalamnya terkandung sebuah syarat bagi calon penyewa yaitu haruslah seorang muslim. Bentuk penawaran seperti ini menunjukkan preferensi pemilik bangunan terhadap penyewa. Artinya pemilik bangunan telah memilih dengan siapa ia ingin membuat perjanjian sewamenyewa. Hal ini dinilai masih sejalan dengan makna "Bebas memilih dengan siapa ingin membuat perjanjian".

Tindakan pemasangan papan tersebut harus dibedakan dengan pembatasan dengan sebuah larangan terhadap kelompok tertentu dalam tahap pra kontrak misal dengan memasang papan "Tidak Menerima Kost Muslim". Dalam penawaran tersebut terlihat kelompok orang yang tidak dikehendaki oleh pemilik bangunan dalam membuat perjanjian sewa-menyewa. Makna bebas memilih dengan siapa seseorang ingin membuat perjanjian tidak sama dengan bebas memilih tidak dengan siapa seseoranb ingin membuat perjanjian yang mempunyai makna negatif. Selain makna tidak dengan siapa seseorang ingin membuat perjanjian tidak disebutkan dalam cakupan kebebasan berkontrak, tindakan tersebut kepatutannya dapat dipertanyakan.

Pemilik tempat tinggal memilih-milih calon penyewa berdasarkan karakter karena ia memiliki kepentingan dalam perlindungan fungsi bisnisnya. ${ }^{14}$

${ }^{13}$ Faktor karakter (Character) sebagai bagian dari 5C merupakan salah satu bahan pertimbangan yang penting dalam perjanjian kredit, karena karakter seseorang mempengaruhi kelancaran pelaksanaan perjanjian kredit.

${ }_{14}$ Dalam doktrin Duty to Serve yang melarang diskriminasi oleh pihak yang menyediakan pelayanan bagi publik, perlindungan fungsi bisnis dapat menjadi suatu alasan untuk mengecualikan atau menolak pihak lain dalam berkontrak. Harvard Law Review Association, "The Antidiscrimination Principle in The Common Law", 102 Harv. L. Rev. 1993, 1989, hlm 1995. 
Pelaksanaan perjanjian sewa menyewa kost antara pemilik tempat tinggal dan penyewa tidak hanya berpengaruh kepada masing-masing pihak, tetapi juga berpengaruh terhadap masyarakat sekitar. Keamanan dan moral masyarakat sekitar bisa saja terancam jika pendatang yang tinggal di kost memiliki karakter yang buruk dan tidak mematuhi norma-norma yang ada di masyarakat sekitar. Jika terjadi hal-hal yang tidak diinginkan, tidak hanya masyarakat tetapi juga pemilik tempat tinggal akan dirugikan karena nama baiknya akan tercemar pada akhirnya.

Mengetahui karakter seseorang yang sesungguhnya kenyataannya memang tidak mudah, apalagi melalui tahap negosiasi sewa kost yang sangat singkat. Dalam hal ini pemilik tempat tinggal hanya bisa menentukan karakter calon penyewa melalui informasi yang tersedia dimana pada tahap negosiasi yang diketahui adalah nama, daerah asal, status, pekerjaan, dan agama yang tercantum dalam KTP. Dalam situasi seperti ini biasanya pemilik tenpat tinggal hanya bisa berasumsi mengenai karakter calon penyewa dengan subjektifitas terhadap ras, asal daerah atau agamanya. Dalam penelitian yang dilakukan di beberapa kota di Amerika Serikat pada tahun 2011 diskriminasi terhadap Afro-Amerika terjadi ketika pemilik tempat tinggal tidak memiliki informasi yang lengkap tentang calon penyewa, sehingga mereka bergantung kepada karakteristik yang terlihat. ${ }^{15}$

Perjanjian sewa-menyewa tempat tinggal kost sedikit berbeda dengan sewa menyewa rumah pada umumnya, karena pada sewa kost penyewa tinggal bersama penyewa lain dan atau dengan pemilik tempat tinggal atau induk semang, sehingga preferensi terhadap pihak yang memeluk agama yang sama atau berasal dari ras yang sama terasa lebih kental. Agama yang dipeluk serta identitas etnis mempengaruhi kerjasama antar individu dengan agama atau etnis yang sama. ${ }^{16}$ Dalam penelitian yang sama terdapat tendensi pihak fundamentalis yang cenderung berprasangka terhadap pihak yang berlawanan dengan keyakinannya.

15 Diskriminasi tidak terjadi ketika permohonan untuk menyewa dilakukan oleh Afro-Amerika yang menggunakan identitas yang menunjukkan status sosial yang tinggi (bigh class). Andrew Hanson \& Zackary Hawley, "Do Landlords Discriminate in The Rental Housing Market? Evidence from an Internet Field Experiment in US Cities", Journal of Urban Economics 70 (2011).

16 Swee-Hoon Chuah et. al., "Religion, Ethnicity and Cooperation: An Experimental Study", Journal of Economic Psychology 45 (2014). 
Studi lain juga menunjukkan bahwa agama menjadi dasar pendorong keinginan individu untuk membantu sesama pemeluk yang membutuhkan. ${ }^{17}$

\section{Pembatasan dalam "Bebas Memilih dengan Siapa Seseorang Ingin Membuat Perjanjian" pada Pemasangan Papan "Terima Kost Muslim"}

Asas kebebasan berkontrak adalah refleksi dari perkembangan paham pasar bebas yang dipelopori oleh Adam Smith. Dalam perkembangannya ternyata kebebasan berkontrak dapat mendatangkan ketidakadilan karena prinsip ini hanya dapat mencapai tujuannya, yaitu mendatangkan kesejahteraan seoptimal mungkin, bila para pihak memiliki bargaining power yang seimbang. ${ }^{18}$

Dalam praktiknya, asas ini kerap kali kurang dipahami secara utuh, sehingga banyak memunculkan pola hubungan kontraktual yang tidak seimbang dan berat sebelah dalam arti bargaining power tidak seimbang antara para pihak. Dalam kasus pencantuman papan "Terima Kost Muslim", pihak yang menyewakan memiliki posisi yang lebih tinggi dari penyewa karena dapat secara sepihak menentukan menyewakan kost hanya untuk penyewa yang beragama Islam atau muslim.

Kebebasan berkontrak di dalam perkembangannya, hanya bisa mencapai tujuannya apabila para pihak mempunyai bargaining position yang seimbang. Teori kebebasan berkontrak ini dihadapkan dengan kenyataan yang terjadi dalam pasar pada awal 1900an. Tidak ada pihak yang seimbang dalam tawar-menawar. Pihak yang mempunyai posisi tawar tinggi menekan pihak yang lebih lemah. Saat itu praktek penyalahgunaan dalam transaksi tumbuh subur seperti penjualan barang dan obat yang tercemar, eksploitasi buruh, serta banyaknya produk dan jasa yang cacat di pasar. ${ }^{19}$

Jika salah satu pihak lemah maka pihak yang memiliki bargaining position lebih kuat dapat memaksakan kehendaknya untuk menekan pihak lain demi keuntungan dirinya sendiri. Syarat-syarat atau ketentuan-ketentuan dalam kontrak yang semacam itu akhirnya akan melanggar aturan-aturan yang adil dan layak. Di dalam kenyataanya, tidak selalu para pihak memiliki bargaining position

${ }_{17}$ Saroglou V et. al., Speak, Lord, Your Servant is Listening: Religious Priming Activates Submissive Thoughts and Behaviors, International Journal on the Psychology of Religion 19, 143-154. dalam Swee-Hoon Chuah et. al., Religion, Ethnicity and Cooperation: An Experimental Study, Journal of Economic Psychology 45 (2014).

18 http://wartawarga.gunadarma.ac.id/2011/03/hukum-perjanjian-7/, diakses tanggal 7 Juli 2011.

${ }^{19}$ Carolyn Edwards, Freedom of.., Op. Cit., hlm. 648. 
yang seimbang sehingga Negara campur tangan untuk melindungi pihak yang lemah. ${ }^{20}$

Kebebasan berkontrak tidak berlaku secara mutlak atau tanpa batasan, sehingga dapat dikatakan kebebasan berkontrak tidak tak terbatas, ada pembatasan-pembatasan terhadap berlakunya asas ini. Pembatasan terhadap berlakunya asas kebebasan berkontrak dimaksudkan untuk mencegah dari penyalahgunaan kekuasaan yang disebabkan oleh ketimpangan posisi tawar dari salah satu pihak yang lebih dominan dibandingkan pihak lain yang lebih lemah.

Kebebasan berkontrak harus terikat pada batas-batas tertentu, akan tetapi jika batas-batas tersebut terlampau sempit, maka sirnalah rasa hormat kepada UndangUndang dan hukum serta akan terjadi kesenjangan antara apa yang menurut hukum adil dan benar dan apa yang menurut tolok ukur moral dan kesusilaan sesuatu yang pantas. ${ }^{21}$

Pada prinsipnya para pihak dalam perjanjian bebas untuk menentukan aturan main yang dikehendaki dan kemudian melaksanakannya sesuai kesepakatan bebas dari para pihak yang cakap untuk bertindak demi hukum, untuk melaksanakan suatu prestasi tertentu, dan sepanjang tidak bertentangan dengan peraturan perUndang-Undangan, ketertiban umum, kepatutan, kesusilaan dan kebiasaan yang berlaku di dalam masyarakat.

Konsep kebebasan berkontrak dalam perjanjian sewa menyewa juga didukung oleh konsep hak milik (eigendom) dalam hukum benda. Hak milik menurut KUH Perdata adalah hak untuk menikmati suatu barang secara leluasa dan untuk berbuat terhadap barang itu secara bebas sepenuhnya. Eigendom dahulu dipandang sebagai hak yang sungguh-sungguh mutlak, dalam arti tak terbatas. ${ }^{22}$ Pemegang hak milik atas benda memiliki kebabasan dalam menikmati dan dalam melakukan perbuatan hukum terhadap benda tersebut, termasuk perbuatan menyewakan.

Sewa menyewa kamar pada dasarnya adalah perbuatan menyewakan sebagian dari bangunan yang berdiri di atas tanah, sehingga masih terdapat kaitan

${ }^{20}$ Sutan Remy Sjahdeini, Op. Cit. hlm. 8-9.

21 Soedjono Dirdjosisworo, Kontrak Bisnis Menurut Sistem Civil Law, Common Law, dan Praktek Dagang Internasional), Mandar Maju, Bandung, 2003, hlm. 118.

22 Subekti, Pokok-Pokok Hukum Perdata, Cetakan ke-15, Intermasa, Jakarta, 1980. 
dengan hak atas tanah yang diatur dalam Undang-Undang Pokok Agraria (UUPA). Berdasarkan Pasal 6 dan 7 UUPA Semua hak atas tanah termasuk hak milik mempunyai fungsi sosial dan tidak boleh merugikan kepentingan umum. Dalam Pasal 570 KUH Perdata, penggunaan hak milik dibatasi oleh peraturan perundangundangan dan tidak mengganggu hak-hak orang lain.

\section{Kebebasan Memilih Pihak dalam Perjanjian dan Prinsip Anti-Diskriminasi}

Pada dasarnya dalam seluruh proses pembentukan kontrak sesungguhnya mengandung diskriminasi. ${ }^{23}$ Dalam hal sumber daya yang menjadi objek perjanjian merupakan sesuatu yang langka tentu saja tidak semua orang bisa mendapatkan kesempatan untuk menjadi pihak dalam perjanjian. Proses pemilihan pihak menjadi tidak terhindarkan. Bahkan dalam perjanjian yang serupa seorang pihak bisa memberikan syarat dan ketentuan yang berbeda pada tiap perjanjian karena terdapat risiko atau biaya lebih yang timbul dalam berkontrak dengan salah satu pihak tersebut. ${ }^{24}$

Perjanjian berada pada alam privat dimana individu bisa mewujudkan kepentingannya tanpa diperintah dan dikendalikan oleh badan publik. Akan tetapi kontrak merupakan bagian dari pasar sehingga kontrak tidak dapat sepenuhnya dilepaskan dari pengawasan dan pengaturan publik. ${ }^{25}$ Pelaksanaan kebebasan dalam memilih pihak dalam titik tertentu dapat menjadi bertentangan dengan kepentingan publik jika mengandung diskriminasi ras, jenis kelamin, dan karakteristik lain. ${ }^{26}$

Di negara seperti Amerika Serikat kebebasan untuk membuat perjanjian merupakan bagian dari hak-hak dasar yang dilindungi dalam konstitusi. ${ }^{27}$ Hak seorang individu untuk memilih pihak dalam berkontrak adalah persimpangan antara hak-hak dasar dan teori dasar kontrak. Kebebasan memilih pihak membantu mewujudkan harapan individu melalui preferensi dalam transaksi. ${ }^{28}$ Di sisi lain

${ }^{23}$ Michael J. Trebilcock, The Limit of Freedom of Contract, Harvard University Press, United States, 1993, hlm.

${ }^{24}$ Ibid.

${ }^{25}$ Hugh Collins, The Vanishing..., Op. Cit., hlm. 73.

${ }^{26}$ Ibid.

${ }^{27}$ Kirsten L. McCaw, Freedom of Contract Versus The Antidiscrimination Principle: A Critical Look at The Tension Between Contractual Freedom and Antidiscrimination Provisions, 7 Seton Hall Const. L.J. 195, 1996, hlm. 196.

${ }^{28}$ Hugh Collins, The V anishing.., Loc. Cit. 
kebebasan dalam memilih pihak juga bermakna kebebasan untuk menolak seseorang sebagai pihak berkontrak. Penolakan ini dapat memberikan dampak seperti hilangnya kesempatan kerja dan kesempatan untuk mendapatkan pelayanan. ${ }^{29}$

Asas anti-diskriminasi adalah sebuah konsep dimana pengklasifikasian orang berdasarkan karakteristik-karakteristik tertentu dilarang. ${ }^{30}$ Terdapat dua bentuk diskriminasi yaitu diskriminasi langsung dimana seseorang diperlakukan berbeda (less favourable) daripada lainnya dan diskriminasi tidak langsung yang muncul sebagai dampak dari hukum atau dalam praktek hukum. ${ }^{31}$ Diskriminasi mengakibatkan kesenjangan perbedaan perlakuan yang seharusnya setara, maka dari itu negara tidak boleh secara sengaja mengabaikan hak-hak dan kebebasankebebasan orang. Negara memiliki kewajiban untuk melindungi secara aktif dan memastikan terpenuhinya hak-hak dan kebebasan. ${ }^{32}$

Pemilihan pihak dalam sewa menyewa kamar berdasarkan preferensi agama ini merupakan bentuk Private Discrimination, artinya tindakan diskriminasi yang dilakukan oleh orang privat (private person). Di sistem hukum Amerika Serikat segala jenis Private Discrimination masih dapat dibenarkan, kecuali secara spesifik dilarang oleh undang-undang negara bagian atau federal. ${ }^{33}$

Diskriminasi dalam Undang-Undang No. 39 Tahun 1999 tentang Hak Asasi Manusia (UU HAM) dimaknai sebagai:

" Setiap pembatasan, pelecehan, atau pengucilan yang langsung ataupun tak langsung didasarkan pada pembedaan manusia atas dasar agama, suku, ras, etnik, kelompok, golongan, status sosial, status ekonomi, jenis kelamin, bahasa, keyakinan politik, yang berakibat pengurangan, penyimpangan atau penghapusan pengakuan, pelaksanaan atau penggunaan hak asasi manusia dan kebebasan dasar dalam kehidupan baik individual maupun kolektif dalam bidang politik, ekonomi, hukum, sosial, budaya, dan aspek kehidupan lainnya."

29 Ibid.

${ }^{30}$ Kirsten L. McCaw, "Freedom..", Op. Cit., hlm. 203.

${ }^{31}$ Knut D. Asplund, Suparman Marzuki Ed., Et. al., Hukum Hak Asasi Manusia, Cetakan Pertama, PUSHAM UII, Yogyakarta, 2008, hlm. 40.

${ }^{32}$ Ibid.

33 Garrett Epps, Public Accomodations and Private Discrimination, https://www.theatlantic.com/politics/ archive/2015/04/public-accommodations-and-private-discrimination/390435/, diakses pada 21 Mei 2018. 
Pelarangan diskriminasi diatur dalam Pasal 3 yang menyatakan bahwa setiap orang berhak atas perlindungan hak asasi manusia dan kebebasan dasar manusia tanpa diskriminasi.

Dalam mengkaji asas kebebasan berkontrak dan anti-diskriminasi di Indonesia, perlu dilihat apakah kebebasan berkontrak atau hak untuk diperlakukan setara dalam perjanjian merupakan bagian dari kebebasan dasar manusia. Cakupan Hak Asasi Manusia dan Kebebasan Dasar Manusia dalam UU HAM diatur dalam Bab III yang meliputi hak untuk hidup, hak berkeluarga dan melanjutkan keturunan, hak mengembangkan diri, hak memperoleh keadilan, hak atas kebebasan pribadi, hak atas rasa aman, hak atas kesejahteraan, hak turut serta dalam pemerintahan, hak wanita, hak anak. Dari semua hak dan kebeasan dasar tersebut belum ada pasal yang mencakup kebebasan berkontrak di dalamnya.

Dalam bagian hak atas kesejahteraan salah satu cakupannya adalah hak untuk bertenpat tinggal serta berkehidupan yang layak yang disebutkan dalam Pasal 40. Kaitannya dengan sewa-menyewa tempat tinggal kost adalah pada dasarnya semua manusia di Indonesia berhak atas tempat tinggal yang layak. Sebagai bagian dari hak asasi yang perlindungannya dilakukan tanpa diskriminasi, maka dalam mendapatkan tempat tinggal tidak seharusnya didiskriminasi.

Pemasangan plang "terima kost muslim" yang mengkhususkan Muslim untuk dapat tinggal di pondokan tersebut dapat dinilai sebagai bentuk diskriminasi karena ada perlakuan yang berbeda (less favourable), karena hanya pemeluk Agama Islam saja yang bisa tinggal. Meskipun begitu tindakan ini belum merupakan pelanggaran atas pelarangan diskriminasi yang diatur dalam Pasal 3, karena tidak menyebabkan pemeluk agama lain kehilangan hak untuk mendapatkan tempat tinggal yang layak. Di Indonesia masih banyak sekali pondokan atau tempat kost yang menerima segala golongan untuk tinggal di sana.

\section{Kebebasan Memilih Pihak dalam Perjanjian Dibatasi oleh Peraturan Perundang-Undangan}

Di negara seperti Amerika Serikat diskriminasi ras dalam masyarakat telah menjadi maslah yang serius sampai saat ini. Keinginan dan komitmen untuk menghapus diskriminasi dituangkan ke dalam beberapa peraturan perundangundangan tentang hak-hak sipil. Terdapat beberapa klausula yang melarang 
diskriminasi pada beberapa kategori hubungan kontraktual seperti ketenagakerjaan, tempat tinggal, dan transaksi kredit. ${ }^{34}$

Diskriminasi dalam mendapatkan tempat tinggal di Amerika Serikat dialami oleh beberapa ras minoritas seperti Afro-Amerika dan Hispanic. Segregasi tempat tinggal walaupun sudah mulai menurun, masih terasa menonjol di beberapa kota kontemporer di Amerika Serikat. ${ }^{35}$ Menurut penelitian yang dilakukan oleh Pager dan Shepherd, warga Afro-Amerika mengalami perlakuan yang tidak menyenangkan pada setiap satu diantara lima sedangkan warga Hispanic satu dari empat pencarian rumah (sewa maupun jual beli). ${ }^{36}$ Bentuk diskriminasi yang dialami dalam pencarian tempat tinggal adalah dalam bentuk lebih sedikitnya informasi yang ditawarkan atas unit-unit, kesempatan yang lebih sedikit untuk melihat unit, dan dalam hal jual beli rumah pendampingan dan bantuan yang didapatkan lebih sedikit. 37

Dengan latar belakang permasalahan diskriminasi dalam tempat tinggal, pada 1968 Kongres mensahkan Fair Housing Act yaitu undang-undang yang melarang diskriminasi dalam perumahan dan tempat tinggal dan mengamanatkan pemerintah federal untuk lebih proaktif dalam mewujudkan perumahan dan tempat tinggal yang adil di kota-kota dan daerah sub-urban. ${ }^{38}$

Di Indonesia melalui UU No. 39 Tahun 1999 tentang Hak Asasi Manusia sebagaimana diatur dalam Pasal 3 ayat (3) menyatakan bahwa setiap orang berhak atas perlindungan hak asasi manusia dan kebebasan dasar manusia, tanpa diskriminasi. Dengan demikian, kebebasan seseorang dalam memilih para pihak di dalam perjanjian yang merupakan hak asasi manusia yang dilindungi oleh undang-undang harus tanpa diskriminasi.

Pemerintah Indonesia dalam bidang hukum perjanjian telah mengeluarkan suatu kaidah hukum pemaksa baik berupa undang-undang, peraturan pemerintah

\footnotetext{
${ }^{34}$ Neil G. Williams, "Offer, Acceptance, and Improper Considerations: A Common-Law Model for the Prohibition of Racial Discrimination in the Contracting Process", 62 Geo. Wash. L. Rev. 183, 1993, hlm. 185.

35 Devah Pager \& Hana Shepherd, "The Sociology of Discrimination: Racial Discrimination in Employment, Housing, Credit, and Consumer Markets”, Annu Rev Sociol. 2008 January 1; 34, hlm. 8.

${ }^{36} \mathrm{Ibid}$.

${ }^{37}$ Ibid.

${ }^{38}$ Henry G. Cisneros, "With Liberty and Justice for All: How America Can Provide Fair Housing for All Its People”, 1 Hispanic L.J. 53, 1994, hlm. 55.
} 
dan sebagainya. Hal ini dimaksudkan untuk membatasi kebebasan seseorang untuk tidak melanggar rambu-rambu yang telah diatur dalam aturan tersebut. Hal tersebut berguna untuk mewujudkan keseimbangan demi tercapainya keadilan bagi kepentingan pihak-pihak yang membuat perjanjian.

Peraturan-peraturan yang timbul dari norma hukum (kaedah hukum), dibuat oleh penguasa Negara, isinya mengikat setiap orang dan pelaksanaannya dapat dipertahankan dengan segala paksaan oleh alat-alat Negara. Keistimewaan dari norma hukum justru terletak dalam sifatnya yang memaksa, dengan sanksinya berupa ancaman hukuman. ${ }^{39}$ Bahwa undang-undang adalah keputusan kehendak dari satu pihak; perjanjian, keputusan kehendak dari dua pihak; dengan kata lain, bahwa orang terikat pada perjanjian berdasar atas kehendaknya sendiri, pada Undang-Undang terlepas dari kehendaknya. ${ }^{40}$

Hubungan antara pemilik bangunan dan penyewa dapat dikatakan sebagai hubungan antara pelaku usaha dan konsumen yang diatur dalam Undang-undang No. 8 Tahun 1998 tentang Perlindungan Konsumen. Tindakan pemilik bangunan dalam menyewakan beberapa kamar dalam bangunannya merupakan bentuk menyelenggarakan kegiatan usaha. Di sisi lain penyewa menyewa kamar tersebut untuk kepentingan dirinya sendiri.

Salah satu hak konsumen yang tercantum dalam Pasal 4 huruf g UU Perlindungan Konsumen adalah hak untuk diperlakukan atau dilayani secara benar dan jujur serta tidak diskriminatif. Ketentuan pasal ini tidak dijelaskan lebih lanjut dalam pasal lain atau pada penjelasan apakah hak tersebut berlaku dalam tahap pra kontraktual atau kontraktual. Pemasangan papan "Terima Kost Muslim" adalah suatu bentuk invitation to treat atau suatu undangan untuk memasukkan penawaran yang terjadi pada tahap pra kontraktual. Dalam tahap ini belum terdapat interaksi antara pemilik tempat tinggal dan calon penyewa, sehingga tidak melanggar hak konsumen. Lain halnya jika pemilik tempat tinggal tidak memasang papan, kemudian ada calon penyewa yang datang. Setelah pemilik tempat tinggal mengetahui calon penyewa berkeyakinan atau berasal dari suatu suku yang ia tidak suka, pemilik rumah menolak calon penyewa tersebut baik 
secara langsung dengan menyebutkan alasannya atau dengan berbohong bahwa kamar sudah penuh.

Pelaksanaan usaha rumah kost tidak hanya berdampak kepada pemilik tempat tinggal dan penyewa, tetapi juga kepada masyarakat sekitar. Untuk itu beberapa pemerintah daerah di beberapa kabupaten dan kota merasa perlu membuat peraturan yang mengatur agar usaha rumah kost tetap dalam koridor nilai-nilai sosial yang ada pada masyarakat. Perda yang mengatur penyelenggaraan dan pengelolaan usaha kost juga diperlukan untuk pemenuhan kebutuhan tempat tinggal yang tertib, layak, nyaman dan aman bagi pendatang.

Hal-hal yang diatur oleh Perda yang mengatur tentang pengelolaan kost ${ }^{41}$ pada intinya mencakup izin usaha serta hak, kewajiban dan larangan bagi penyelenggara kost dan penyewa. Masyarakat melalui RT dan RW diberi peran untuk pengawasan ketentraman dan ketertiban penyelenggaraan kost di dalam perda. Larangan dalam penyelenggaraan usaha kost dalam kebanyakan Perda adalah larangan menyelenggarakan pondokan yang dihuni penyewa yang berbeda jenis kelamin dalam satu kesatuan bangunan.

Dalam semua Perda penyelenggaraan kost yang ditemukan, belum ditemukan larangan untuk membeda-bedakan calon penyewa kost atau pemasangan plang yang menunjukkan favoritisme terhadap satu golongan masyarakat seperti "terima kost muslim". Terdapat satu klausula dalam Perda Kota Banjarbaru No. 1 Tahun 2013 tentang Pengaturan Usaha Rumah Kost yang melarang pembedaan perlakuan kepada penghuni kost berdasarkan asal-usul, agama, ras, suku dan lain-lain. Namun jika dilihat pelarangan diskriminasi ini hanya kepada penghuni kost yang telah terikat kontrak atau dalam tahap pelaksanaan kontrak, bukan pada tahap pembentukan kontrak.

${ }^{41}$ Beberapa Perda yang mengatur tentang penyelenggaraan sewa tempat tinggal kost menggunakan istilah yang berbeda-beda. Penggunaan istilah "kos" atau "kost" dapat ditemukan di Perda Kota Banjarbaru No. 1 Tahun 2003 tentang Pengaturan Usaha Rumah Kost, Perda Kabupaten Badung No. 24 Tahun 2013 tentang Pengelolaan Rumah Kos, Perda Kota Palangkaraya No. 16 Tahun 2011 tentang Izin Usaha Pengelolaan Rumah Kos dan Barak. Sedangkan istilah "Pondokan" dapat ditemukan di Perda Kota Yogyakarta No. 4 Tahun 2003 tentang Penyelenggaraan Pondokan dan Perda Kota Malang No. 6 Tahun 2006 tentang Penyelenggaraan Usaha Pemondokan. 
Penyelenggaraan usaha kost memang dibatasi oleh peraturan perundangundangan yang berlaku, namun peraturan perundang-undangan yang ada di Indonesia tidak mengatur secara khusus mengenai seleksi atau pemilihan calon penghuni pada tahap pra kontraktual. Sehingga dapat disimpulkan bahwa pemasangan plang "terima kost muslim" tidak dilarang oleh peraturan perundang-undangan yang mengatur penyelenggaraan usaha kost.

\section{Kebebasan Memilih Pihak dalam Perjanjian Dibatasi oleh Norma Kepatutan yang Berlaku di dalam Masyarakat}

Kebebasan para pihak untuk memilih dengan siapa akan berkontrak mendapat batasan dari norma kepatutan yang berlaku di masyarakat. Norma ini merupakan ukuran tentang hubungan yang ditentukan juga oleh rasa keadilan masyarakat. Saat seseorang hendak mengingatkan diri dalam perjanjian harus mengindahkan norma kepatutan dalam masyarakat. Norma merupakan aturan atau ketentuan yang mengatur tingkah laku manusia di dalam masyarakat yang mengikat dan harus ditaati oleh setiap orang yang hidup dalam lingkungan berlakunya norma tersebut. Ada nilai yang menjadi landasan bagi manusia dalam bertindak atau berbuat. Nilai merupakan unsur kejiwaan di balik ketentuan yang mengatur tingkah laku tersebut. ${ }^{42}$

Dalam masyarakat terdapat berbagai golongan dan aliran. Walaupun golongan dan aliran beraneka ragam dan masing-masing mempunyai kepentingan sendiri, akan tetapi kepentingan bersama mengharuskan adanya ketertiban dalam kehidupan masyarakat. Maka norma (suatu aturan) akan memberi batasan aturan yang bersifat perintah dan anjuran serta larangan - larangan. Ketentuan-ketentuan berupa larangan untuk perbuatan-perbuatan yang apabila dilakukan atau tidak dilakukan dapat membahayakan kehidupan bersama, sebaliknya perintahperintah adalah ditujukan agar dilakukan perbuatan-perbuatan yang dapat memberi kebaikan bagi kehidupan bersama. Apabila perilaku warga masyarakat menuruti norma atau kaidah maka perbuatannya dipandang wajar atau normal,

42 http:/ / komunitasgurupkn.blogspot.co.id/2014/08/pengertian-norma-macam-macam-norma-dan.html, diakses tanggal 16 Oktober 2015. 
sebaliknya jika dianggap tidak normal atau menyimpang maka akan menerima reaksi dari masyarakat. ${ }^{43}$

Kepatutan dapat digambarkan sebagai nilai yang patut; pantas; layak; sesuai; cocok; sopan dan beradab, sebagaimana sama-sama dikehendaki oleh masingmasing pihak yang membuat perjanjian. ${ }^{44}$ Dalam konteks kebebasan seseorang untuk memasang papan nama "terima kost muslim" yang dimaksudkan untuk memilih siapa yang dapat menjadi penyewa, sesungguhnya juga ada pembatasannya yaitu berkaitan dengan norma kepatutan yang berlaku di masyarakat. Setiap orang memiliki pola pikir dan tindakan yang dijamin kebebasannnya oleh undang-undang. Namun demikian, kebebasan tersebut harus sesuai dengan ketentuan dan tatanan yang berlaku di masyarakat.

Setiap orang memang memiliki hak untuk memiliki pola pikir untuk menentukan pilihan sesuai dengan keinginannya maupun prinsip tertentu yang diyakininya. Namun apabila kepentingan yang sifatnya individual tersebut akan bertolak belakang bahkan dirasakan tidak patut atau menggangu ketertiban umum, maka akan membawa kepada situasi yang tidak harmonis dan membahayakan kehidupan bersama. Hal ini mengakibatkan rasa keadilan tidak tercapai di masyarakat.

Tindakan dalam menunjukkan preferensi berdasarkan agama penyewa harus ditunjukkan dengan cara-cara yang patut. Seperti yang dibahas sebelumnya, menunjukkan sebuah preferensi berbeda dengan menunjukkan kelompok yang tidak dikehendaki untuk menjadi penyewa. Tindakan memasang papan "Terima Kost Muslim" dalam praktik usaha penyewaan kamar merupakan hal yang lazim dilakukan di Indonesia. Perbuatan ini dimaksudkan untuk menjadi penyaring pihak yang akan melakukan penawaran untuk menjadi penyewa. Pemasangan papan tersebut justru menghindari tindakan diskriminasi dalam tahap negosiasi lebih lanjut ketika pemilik tempat tinggal mengetahui rasa tau agama calon penyewa.

\footnotetext{
43 “Norma atau Kaidah Dalam Masyarakat”, http://dingklikkelas.blogspot.co.id/2014/03/norma-ataukaidah-dalam-masyarakat.html

${ }^{44}$ L.J. Van Apeldoorn, Op. Cit., hlm. 99.
} 


\section{Penutup}

"Bebas memilih dengan siapa seseorang ingin membuat perjanjian" dalam asas kebebasan berkontrak pada pemasangan papan "Terima Kost Muslim" mempunyai makna bahwa pada setiap orang bebas untuk menentukan dengan siapa ia akan menyewakan kamar dalam bangunannya dengan menentukan orang dengan agama apa yang dapat menjadi penyewa kamar.

Kebebasan memilih dengan siapa seseorang ingin membuat perjanjian dalam praktek pemasangan papan "Terima Kost Muslim" dibatasi peraturan perundangundangan seperti Undang-Undang Perlindungan Konsumen dan beberapa Perda terkait dengan usaha penyewaan kamar dan norma kepatutan yang berlaku di dalam masyarakat.

\section{Daftar Pustaka}

\section{Buku}

Badrulzaman, Mariam Darus, KUH Perdata Buku III Hukum Perikatan dengan Penjelasan, Alumni, Bandung, 1993.

Badrulzaman, Mariam Darus, Kompilasi Hukum Perikatan, PT. Citra Aditya Bakti, Bandung, 2001.

Black, Henry C., Black's Law Dictionary, West Publishing, St.Paul, 1979.

Budiono, Herlien, Asas Keseimbangan bagi Hukum Perjanjian Indonesia., PT. Citra Aditya Bakti, Bandung, 2006.

Departemen Pendidikan dan Kebudayaan RI, Kamus Besar Bahasa Indonesia, Rineka Cipta, Jakarta, 1995.

Dirdjosisworo, Soedjono, Kontrak Bisnis (Menurut Sistem Civil Law, Common Law, dan Praktek Dagang Internasional), Mandar Maju, Bandung, 2003

H.S., Salim, Hukum Kontrak, Teori dan Teknik Penyusunan Kontrak, Sinar Grafika, Jakarta, 2006.

Hernoko, Agus Yudha, Hukum Perjanjian, Asas Proporsionalitas dalam Kontrak Komersial, LaksBang Mediatama, Yogyakarta, 2008.

Ibrahim, Johannes, Pengimpasan Pinjaman (Kompensasi) dan Asas Kebebasan Berkontrak Dalam Perjanjian Kredit Bank. CV. Utomo, Bandung, 2003.

Kansil, C.S.T., Pengantar Hukum Dan Tata Hukum Indonesia, Balai Pustaka, Jakarta, 1983.

Khairandy, Ridwan, Hukum Kontrak Indonesia dalam Perspektif Perbandingan (Bagian Pertama), FH UII Press, Yogyakarta, 2014. 
Mertokusumo, Sudikno, Mengenal Hukum (Suatu Pengantar), Liberty, Yogyakarta 1995.

Muhammad, Abdulkadir, Hukum Perikatan, Citra Aditya Bakti, Bandung, 1992.

Partanto, Pius A \& Al-Barry, M. Dahlan, Kamus Ilmiah Populer, Aroka, Surabaya, 1994.

Rajaguguk, Erman, Kontrak Dagang Internasional dalam Praktek di Indonesia, FH UI dan Elips Project, Jakarta, 1994.

Setiawan, R., Aneka Masalah Hukum dan Hukum Acara Perdata, Cet.I, Alumni, Bandung, 1992.

Setiawan, R., Pokok-Pokok Hukum Perikatan, Bina Cipta, Bandung, 1994.

Sjahdeini, Sutan Remy, Kebebasan Berkontrak dan Perlindungan Seimbang bagi Para Pihak dalam Perjanjian Kredit di Indonesia, Institut Bankir Indonesia, Jakarta, 1993.

Sjahdeini, Sutan Remy, Kebebasan Berkontrak dan Perlindungan yang Seimbang Bagi Para Pihak Dalam Perjanjian Kredit Bank di Indonesia, Cetakan Pertama, Pustaka Utama Grafiti, Jakarta, 2009.

Subekti, Aneka Perjanjian, Alumni, Bandung, 1995.

Suhardana, F.X., Contract Drafting (Kerangka Dasar dan Teknik Penyusunan Kontrak), Universitas Atma Jaya, Yogyakarta, 2008.

Trebilcock, Michael J., The Limit of Freedom of Contract, Harvard University Press, United States, 1993.

\section{Jurnal}

Bernestein, David E, "Freedom of Contract", George Mason Law \& Economics Research Paper No. 08-5, George Mason University of Law, 2008.

Cisneros, Henry G., “With Liberty and Justice for All: How America Can Provide Fair Housing for All Its People", 1 Hispanic L.J. 53, 1994

McCaw, Kirsten L., "Freedom of Contract Versus The Antidiscrimination Principle: A Critical Look at The Tension Between Contractual Freedom and Antidiscrimination Provisions", 7 Seton Hall Const. L.J. 195, 1996.

Pager, Devah \& Shepherd, Hana, "The Sociology of Discrimination in Employment, Housing, Credit, and Consumer Market", Annu Rev Spciol. 2008 January 1, 2008.

Rabin, Edward H., "Revolution in Residential Lanlord-Tenant Law: Causes and Consequences", Cornell Law Review Vol. 69, 1984

Williams, Neil G., “Offer, Acceptance, and Improper Considerations: A CommonLaw Model for the Prohibition of Racial Discrimination in the Contracting Process", 62 Geo. Wash. L. Rev. 183, 1993. 


\section{Peraturan Perundang-Undangan}

Undang-Undang Dasar 1945

Kitab Undang-Undang Hukum Perdata

UU Nomor 39 Tahun 1998 tentang Hak Asasi Manusia, Lembaran Negara Republik Indonesia Tahun 1998, Tambahan Lembaran Negara RI Nomor 3886.

Perda Kota Banjarbaru No. 1 Tahun 2013 Tentang Pengaturan Usaha Rumah Kost, Lembaran Daerah Kota Banjarbaru 2013 Nomor 1.

\section{Internet}

Purwanto, Edi, "Eksklusivisme Itu Berlabel Kos Muslim", https://jendelapemikiran.wordpress.com/2008/05/26/ekslusivitasberlabel-kos-muslim/, diakses pada 4 Juli 2015 19:15.

Garrett Epps, "Public Accomodations and Private Discrimination", https://www.theatlantic.com/politics/archive/2015/04/publicaccommodations-and-private-discrimination/390435/, diakses pada 21 Mei 2018. 